\title{
Distribution and habitat preference of Ephemeroptera and Trichoptera in subtropical mountain streams: implications for monitoring and conservation
}

\author{
ROMINA E. PRINCIPE, JAVIER A. MÁRQUEZ and LUCIANA CIBILS-MARTINA \\ Instituto de Ciencias de la Tierra, Biodiversidad y Ambiente (ICBIA), Universidad Nacional de Río Cuarto - CONICET, \\ Departamento de Ciencias Naturales, Ruta Nacional 36 Km 601, X5804BYA, Río Cuarto, Córdoba, Argentina \\ Manuscript received on July 9, 2018; accepted for publication on December 6, 2018
}

\begin{abstract}
How to cite: PRINCIPE RE, MÁRQUEZ JA AND CIBILS-MARTINA L. 2019. Distribution and habitat preference of Ephemeroptera and Trichoptera in subtropical mountain streams: implications for monitoring and conservation. An Acad Bras Cienc 91: e20180692. DOI 10.1590/0001-3765201920180692.
\end{abstract}

\begin{abstract}
The assessment of biotic-habitat relationships provides key information to predict biotic responses to perturbations and important tools for river management and monitoring. This study aimed to assess the spatial distribution of Ephemeroptera and Trichoptera in mountain streams of central Argentina. We evaluated the effect of seasonality and identified the variables conditioning the abundance of the assemblages and the habitat with the highest taxonomic richness. Sampling was carried out in four streams (Carcarañá River basin) during high and low water periods. Three lotic habitats were sampled: riffles, coarse substrate runs, and fine substrate runs; and physicochemical and habitat variables were measured. We found differences in assemblage composition, among the 25 genera of Ephemeroptera and Trichoptera, at the habitat level. The most important variables affecting distribution patterns were substrate and flow type, but macroalgae and organic matter (twigs, leaves, and detritus) were also important predictors. Riffles maintained the highest richness but when considering only the Ephemeroptera taxa, fine substrate runs emerged also as an important habitat for these taxa. Our study provided valuable ecological information related to habitat preference of taxa with a key role in stream functioning and of great usefulness for the monitoring of lotic systems.
\end{abstract}

Key words: Aquatic insects, riffle, run, flow type, substrate.

\section{INTRODUCTION}

The distribution of aquatic insects can be explained as the interaction between hydrogeological conditions and life history of organisms (Statzner et al. 1997, Floury et al. 2017). Drainage basin morphology, slope, effect of tributary streams and local variations of flow and substrate at the habitat level are some of the hydraulic conditions

Correspondence to: Javier Andrés Márquez

E-mail: javier.marquez.zoologia@gmail.com

ORCid: http://orcid.org/0000-0002-4514-3027 that determine organisms distribution (Allan and Castillo 2007, Mac Nally et al. 2011). Habitat provides physical space and food resources for species and these features constitute the templet upon which the evolution forges characteristic traits adapting hence the organisms to the environment (Townsend and Hildrew 1994, Floury et al. 2017). Stream habitats are spatially and temporally dynamic, interacting with structural features of stream channels and hydrological regimes of the landscape (Nestler et al. 2016). Riffles and pools are the most obvious stream habitats that can be 
distinguished in a stream reach (Frissell et al. 1986) and runs are also noticeable in some middle-reach streams (Hawkins et al. 1993).

Distribution patterns of aquatic species strongly depend on changes in hydro-geomorphological conditions operated at different temporal and spatial scales (Mykrä et al. 2007). Several of these changes are produced by human activities which modify stream conditions and alter lotic habitats affecting therefore the aquatic biota (Allan and Castillo 2007). Some of the most sensitive species to disturbances are within the EPT taxonomic group (Ephemeroptera, Plecoptera and Trichoptera) (Resh et al. 1995, Cortes et al. 2013). Richness and abundance of species belonging to these orders strongly decrease with perturbations (Bonada et al. 2006, Ligeiro et al. 2013) altering the structure of the benthic community. The EPT group is often dominant and highly frequent in many lotic systems (Wiggins 1996, Barber-James et al. 2008) and it has also an important role in organic matter breakdown and in the transference of matter and energy in food webs (Hauer and Resh 2017) having, therefore, a key role in the functioning of riverine systems.

The sensitivity to perturbations has made EPT group an important tool in monitoring (Resh et al. 1995, Valente-Neto et al. 2018). Consequently, the evaluation of optimal conditions for these species turns out essential for the development of appropriate monitoring tools and conservation programs. The assessment of biotic-habitat relationships provides key information to predict biotic responses to perturbations (Hawkins et al. 1993, Geist 2011) and important tools for river management, monitoring of ecological integrity and for the development of restoration strategies (Thomson et al. 2001, Gazendam et al. 2016).

Great advances have been made in taxonomy and biogeographical distribution patterns of taxa belonging to the EPT group in latin American counties (i.e. Nieto 2010, Salles et al. 2015, Dos Santos et al. 2015, 2018) but, despite their importance, knowledge about distribution patterns at the habitat level is still fragmentary (but see Baptista et al. 2001, Pérez and Segnini 2005, Brand et al. 2012, Vásquez-Ramos et al. 2014). Moreover, this group acquires increased conservation significance when considering that several genera (and even families) have distributions restricted to this region. This study aims to assess the habitat preference of Ephemeroptera and Trichoptera taxa in third-order mountain streams of central Argentina. We evaluated the effect of seasonality and the influence of variables defining lotic habitats on taxa abundance. We aimed to identify the most important variables influencing the distribution and abundance of the EPT assemblages and the habitat with the highest taxonomic richness. We assume that environmental variables associated with lotic habitats most strongly influence taxa abundance and richness, and thus predicted differences in richness and abundance between habitats and seasonal periods. In addition, since more heterogeneous environments favour the establishment of more diverse communities (Warfe et al. 2008), we expected greater richness and abundance in riffles. In order to evaluate concordance of distribution patterns between Ephemeroptera and Trichoptera, we analyzed separately the respective data set and subsequently we also analyzed the entire matrix to test the pattern of the Ephemeroptera-Trichoptera group as a whole.

\section{MATERIALS AND METHODS}

\section{STUDY AREA}

The study was carried out in four third-order streams of the Carcarañá River upper basin, Córdoba, Argentina: 1) Río de los Sauces stream, 2) El Talita stream, 3) Las Cañitas stream and 4) Piedras Blancas stream (Fig. 1, see also Supplementary Material - Table SI). The study streams belong to one of the most important lotic systems in the central region of Argentina supplying drinking water, 


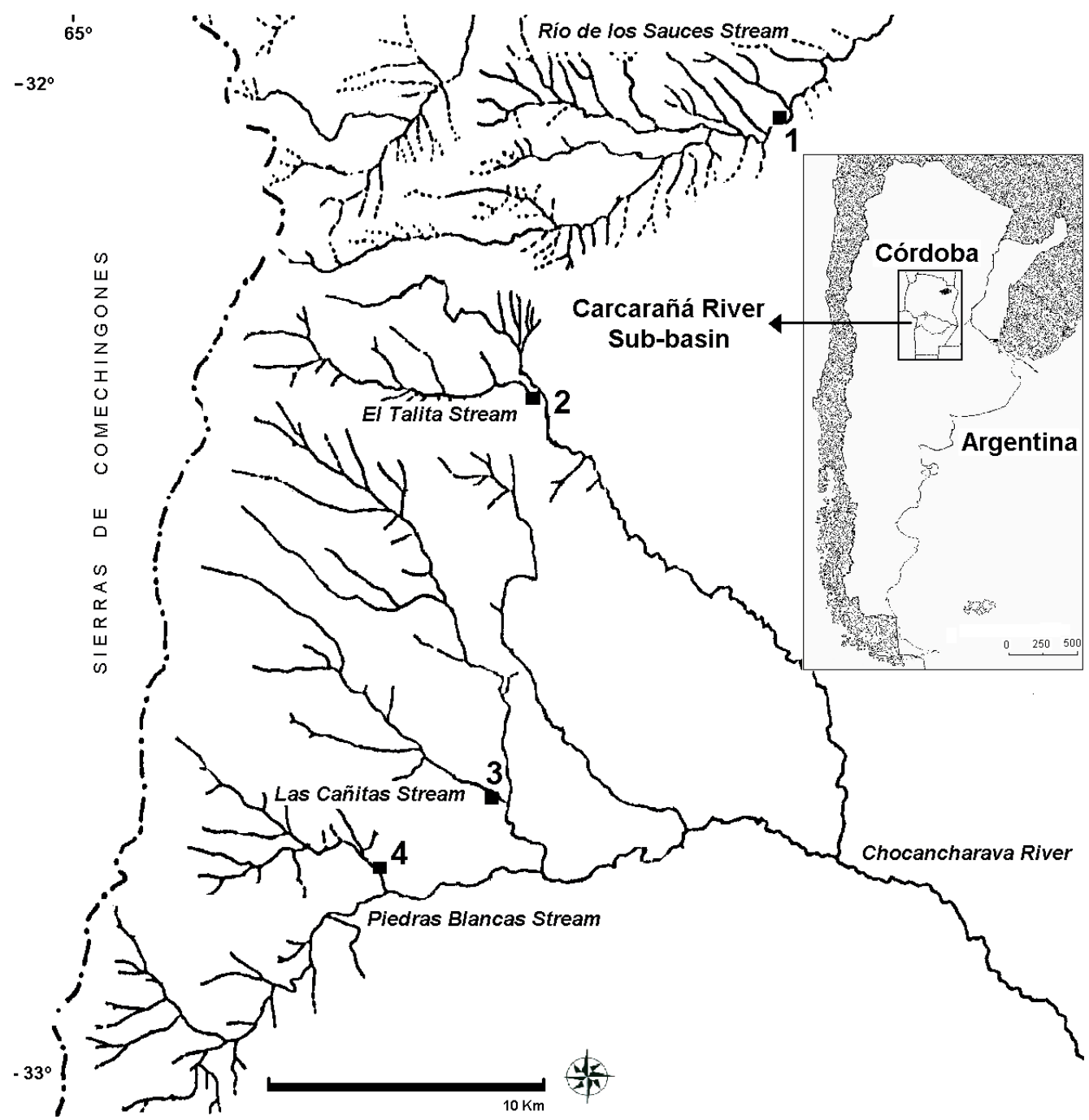

Figure 1 - Study streams in the Carcarañá River Basin, Córdoba, Argentina: (1) Río de los Sauces, (2) El Talita, (3) Las Cañitas, (4) Piedras Blancas.

irrigation, and hydroelectric energy. Headwaters are in mountainous regions at about $2000 \mathrm{~m}$ a.s.1., where many small streams join to form the main collectors at foothills. Then, they flow through the Pampean plain from west to east into the Carcarañá River. Streams in the upper sections have generally deep and narrow valleys, with riffles of coarse substrate and turbulent flow. In lower slope reaches, the stream bed is also composed of gravel and sand. The hydrology of this lotic system is very dynamic, with short and intense floods in specific periods of the year. Annual precipitations reach $725 \mathrm{~mm}$ and occur mainly during the rainy season from October to March (Cabido et al. 2003). Maximum temperature reaches $34{ }^{\circ} \mathrm{C}$ in summer (December-March) and decreases to as low as - 5 ${ }^{\circ} \mathrm{C}$ in winter (June-September). Vegetation of the study area changes in relation to the longitudinal gradient and its distribution is modified by human activities. Some typical tree species are Vachellia caven (Molina) Seigler \& Ebinger, Geoffroea decorticans (Gillies ex Hook. \& Am.) Burkart and Celtis ehrenbergiana (Klotzsch) Liebm. These species occur isolated along the stream banks and in the adjacent areas (Cabido et al. 2003). In some 
reaches, there are also exotic species of ornamental trees and bushes.

\section{SAMPLING AND LABORATORY METHODS}

Sampling was carried out in the four streams during high (March 2003) and low water period (July 2003) (Fig. 2). All streams were visited twice in each period since temporal replication is required to be sure that there are, in fact, seasonal differences in abundance (Underwood 1994). At each stream, two reaches separated by about 300 $\mathrm{m}$ were selected. Three different lotic habitats were selected in each reach: 1) riffles, 2) coarse substrate runs and 3) fine substrate runs. Runs were considered two different habitats due to the contrasting substrate phenology; coarse substrate was mainly composed by boulder and cobble and fine substrate was characterized by gravel and sand. Three replicate benthic samples were taken in each habitat, each one at different riffles and runs; following a stratified sampling design. A total of 288 benthic samples were collected (4 streams, 2 reaches, 2 hydrological periods, 2 dates, 3 habitats and 3 replicates) (Fig. 2).

Benthic samples were taken using a Surber sampler $\left(0.09 \mathrm{~m}^{2}, 300 \mu \mathrm{m}\right.$ mesh size $)$ and invertebrates were preserved in $80 \%$ ethanol. At the laboratory, organisms were sorted and counted. Abundance was calculated as number of individuals per $\mathrm{m}^{2}$. Identifications were made with specialized keys (Domínguez and Fernández 2009) to the genera level since keys for identification of Trichoptera larval stages at the species level are scarce and adults are required (Angrisano and Sganga 2009). Furthermore, the identification to genus has been shown to be appropriate in ecological research, given the noticeable congruence of the data with those obtained for species (Lenat and Resh 2001, Melo 2005).

In order to characterize study streams, wet width was measured with a measuring tape and

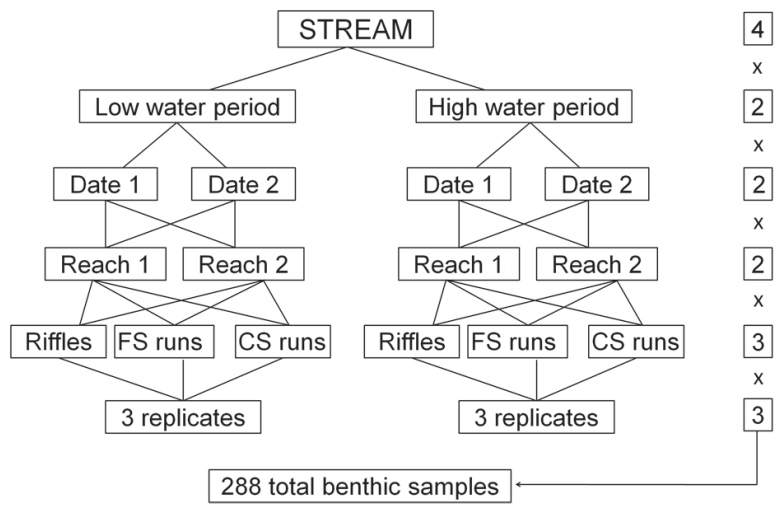

Figure 2 - Sampling design applied in each of the four study streams. The numbers on the right refers to the 4 streams, 2 reaches, 2 hydrological periods, 2 dates, 3 habitats and 3 replicates that were considered in a nested design in the study.

conductivity, $\mathrm{pH}$ and water temperature were measured with portable sensors (HACH CO150, HANNA Checker and HANNA Checktemp; respectively) on each sampling occasion. Turbidity, dissolved oxygen measurements and water chemical analyses were performed using the portable laboratory Hach 2000 and colorimetric analyses (Greenberg et al. 1992). Additionally, we measured variables at the habitat level to relate to the abundance of Ephemeroptera and Trichoptera taxa. Percentages of bedrock, boulder, cobble, pebble, gravel and sand were estimated using a $0.6 \times 0.6 \mathrm{~m}$ grid. The grid was situated in the same place in which each surber were taken, then a estimated measure of substrate for each surber sample was obtained. Flow type above the grid was also visually assessed (Gordon et al. 2004) and assigned to a category according to Thomson et al. (2001). In this study we considered the following flow categories: 1) smooth surface flow, 2) rippled, 3) unbroken standing waves and 4) broken standing waves. The proportional abundance of 1) macrophytes, 2) macroalgae, 3) twigs and leaves, and 4) detritus were also visually assessed with the grid. Macrophytes were distinguished into 1.1) emergent, 1.2) floating, and 1.3) submerged. Current velocity and depth were also measured 
with a Global Flow Probe FP101 in the same place in which each surber sample was taken.

\section{DATA ANALYSES}

A principal component analysis (PCA) was performed to ordinate sites according to the habitat variables which were standardized prior to analysis. Linear mixed models (LMM) were applied to assess the effect of habitat and hydrological period on the abundance of different Ephemeroptera and Trichoptera taxa with relative frequency $>10 \%$ (i.e., taxa collected in at least 29 samples from a total of 288). According to the sampling design, Habitat (riffles, coarse substrate runs, fine substrate runs) and Period (high water and low water) were considered fixed factors and interactions were also analyzed. Stream and Reach were included in the model as random factors with replicates nested within Reach and Reach nested within Stream. Dates in each hydrological period were included in the model as a random factor nested within Period. Validations of simple assumptions of the models were performed reviewing standardized residuals vs. predicted and the normal Q-Q plot of standardized residuals. Abundance data were $\log _{10} Y$ transformed to meet the assumptions for the analyses except for the abundance of Nanomis spp., Protoptila spp. y Oxyethira spp., which were transformed to square root. DGC test (Di RienzoGuzman-Casanoves), a hierarchical method that controls type I error while maintaining acceptable power, was used for multiple comparisons. LMMs were performed using InfoStat (Di Rienzo et al. 2012) that implements an interface of platform $R$ for estimating linear mixed models (R Core Team 2013).

Rarefaction curves were performed using PAST version 3.13 (Hammer et al. 2001) to compare richness of 1) Ephemeroptera, 2) Trichoptera and 3) Ephemeroptera +Trichoptera among the different habitats in the two hydrological periods. This method allows comparison of the number of taxa expected per habitat, based on the lowest number of individuals recorded among the habitats being compared. In addition, assemblage variation between habitat types was tested by applying the Non Metric Multidimensional Scaling (NMDS) to the Ephemeroptera and Trichoptera data set separately and also to Ephemeroptera + Trichoptera. The Bray-Curtis similarity coefficient was used and density values were $\log _{10}(Y+1)$ transformed prior to analysis. Differences among groups defined by NMDS were tested by analyses of similarities (ANOSIM) using PAST version 3.13 (Hammer et al. 2001).

After testing a significant effect of the habitat type on the assemblages with NMDS and ANOSIM, we assessed the influence of habitat variables on taxa distribution by using two Redundancy Analyses (RDA), one considering Ephemeroptera taxa and the other for Trichoptera taxa. RDA is based on a linear model for species responses, rather than a unimodal model as in the Canonical Correspondence Analysis (Mc Cune et al. 2002), then it becomes a more appropriate canonical analysis when the gradient of environmental variation is small, as it is in this study. In canonical analyses, arrows represent habitat variables and the longer the arrow, the stronger the relationship of that variable with the assemblage (Mc Cune et al. 2002). Abundance data were $\log _{10}(Y+1)$ transformed and Restricted Monte Carlo permutation tests were performed (199 permutations) to test the significance of taxaenvironment relationships. Restricted permutations favoured the null model (completely random permutations) because benthic samples were collected in a special temporal and spatial structure (sampling scheme) (ter Braak and Smilauer 1998). Under this permutation scheme, in each RDA only samples collected in the same period and belonging to the same habitat were permuted. RDAs were performed using the statistical package CANOCO version 4.02 (ter Braak and Smilauer 1999). 


\section{RESULTS}

Values of physicochemical variables measured in order to characterize study streams are shown in the supplementary material (Table SI). Current velocity varied among the different habitat types (Table I) showing the highest mean value in riffles during the high water period $\left(0.64 \mathrm{~m} . \mathrm{s}^{-1}\right)$ and the lowest value in fine substrate runs during the low water period $\left(0.22 \mathrm{~m} \cdot \mathrm{s}^{-1}\right)$. Riffles presented two different flow types: broken and unbroken standing waves. In coarse substrate runs flow type was rippled in all cases and fine substrate runs presented rippled and smooth surface flow. The substrate in riffles was mainly composed by boulder (34\% and $22 \%$, high and low water period respectively) and cobble (43\% and $51 \%$, high and low water period respectively) (Table I). Runs with coarse substrate also included high percentages of boulder (16\% and 25\%, high and low water respectively) and cobbles (49\% and $45 \%$, high and low water respectively) but pebble was also present at this habitat type (24\% and $18 \%$, high and low water respectively). Finally, runs with fine substrate were composed by gravel (51\% and $59 \%$, high and low water period respectively) and sand $(30 \%$ and $40 \%$, high and low water period respectively).

PCA performed with habitat variables showed that fine substrate runs were clearly separated from riffles and coarse substrate runs (Fig. 3a). The first two PCA axes explained $47.32 \%$ of the variation

TABLE I

Characterization of habitat types sampled during low and high water periods and Pearson's correlation coefficients between habitat variables and principal component analysis (PCA) axes scores (Values $\geq 0.6$ are in bold). Mean values of habitat variables are shown with the corresponding minimum and maximum value below.

\begin{tabular}{|c|c|c|c|c|c|c|c|c|}
\hline & \multicolumn{2}{|c|}{ RIFFLES } & \multicolumn{2}{|c|}{$\begin{array}{c}\text { COARSE SUBSTRATE } \\
\text { RUNS }\end{array}$} & \multicolumn{2}{|c|}{ FINE SUBSTRATE RUNS } & \multicolumn{2}{|c|}{$\begin{array}{c}\text { Pearson } \\
\text { correlation }(r)\end{array}$} \\
\hline & High water & Low water & High water & Low water & High water & Low water & Axis 1 & Axis 2 \\
\hline \multirow[t]{2}{*}{$\begin{array}{l}\text { C. velocity } \\
\left(\mathrm{m} \cdot \mathrm{s}^{-1}\right)\end{array}$} & 0.64 & 0.56 & 0.39 & 0.26 & 0.34 & 0.22 & 0.26 & -0.29 \\
\hline & $(0.10-1.18)$ & $(0.11-1.80)$ & $(0.06-0.82)$ & $(0.06-0.74)$ & $(0.07-0.55)$ & $(0.06-0.78)$ & & \\
\hline \multirow[t]{2}{*}{ Depth (m) } & 0.22 & 0.20 & 0.23 & 0.24 & 0.25 & 0.26 & -0.29 & -0.37 \\
\hline & $(0.05-0.53)$ & $(0.05-0.40)$ & $(0.07-0.49)$ & $(0.09-0.42)$ & $(0.07-0.46)$ & $(0.08-0.70)$ & & \\
\hline Flow type & $\begin{array}{l}\text { Unbroken } \\
\text { standing } \\
\text { waves }\end{array}$ & $\begin{array}{l}\text { Broken - } \\
\text { unbroken } \\
\text { standing } \\
\text { waves }\end{array}$ & Rippled & Rippled & Rippled & $\begin{array}{c}\text { Rippled } \\
\text { - Smooth } \\
\text { surface flow }\end{array}$ & 0.71 & -0.06 \\
\hline \multirow[t]{2}{*}{$\%$ Bedrock } & 18 & 10 & 0 & 0 & 0 & 0 & 0.19 & -0.80 \\
\hline & $(0-80)$ & $(0-80)$ & $(0-0)$ & $(0-0)$ & $(0-0)$ & $(0-0)$ & & \\
\hline \multirow[t]{2}{*}{$\%$ Boulder } & 34 & 22 & 16 & 25 & 0 & 0 & 0.71 & 0.42 \\
\hline & $(0-50)$ & $(0-50)$ & $(0-50)$ & $(0-50)$ & $(0-0)$ & $(0-0)$ & & \\
\hline \multirow[t]{2}{*}{$\%$ Cobble } & 43 & 51 & 49 & 45 & 10 & 0 & 0.92 & 0.15 \\
\hline & $(20-60)$ & $(20-60)$ & $(33-60)$ & $(33-60)$ & $(0-60)$ & $(0-0)$ & & \\
\hline \multirow[t]{2}{*}{$\%$ Pebble } & 4 & 13 & 24 & 18 & 9 & 1 & 0.28 & -0.22 \\
\hline & $(0-30)$ & $(0-30)$ & $(0-50)$ & $(0-50)$ & $(1-33)$ & $(1-5)$ & & \\
\hline \multirow[t]{2}{*}{ \% Gravel } & 1 & 4 & 11 & 11 & 51 & 59 & -0.97 & 0.08 \\
\hline & $(0-10)$ & $(0-10)$ & $(0-33)$ & $(0-33)$ & $(10-60)$ & $(30-60)$ & & \\
\hline \multirow[t]{2}{*}{$\%$ Sand } & 0 & 0 & 0 & 0 & 30 & 40 & -0.94 & 0.12 \\
\hline & $(0-0)$ & $(0-0)$ & $(0-0)$ & $(0-0)$ & $(0-40)$ & $(30-40)$ & & \\
\hline
\end{tabular}



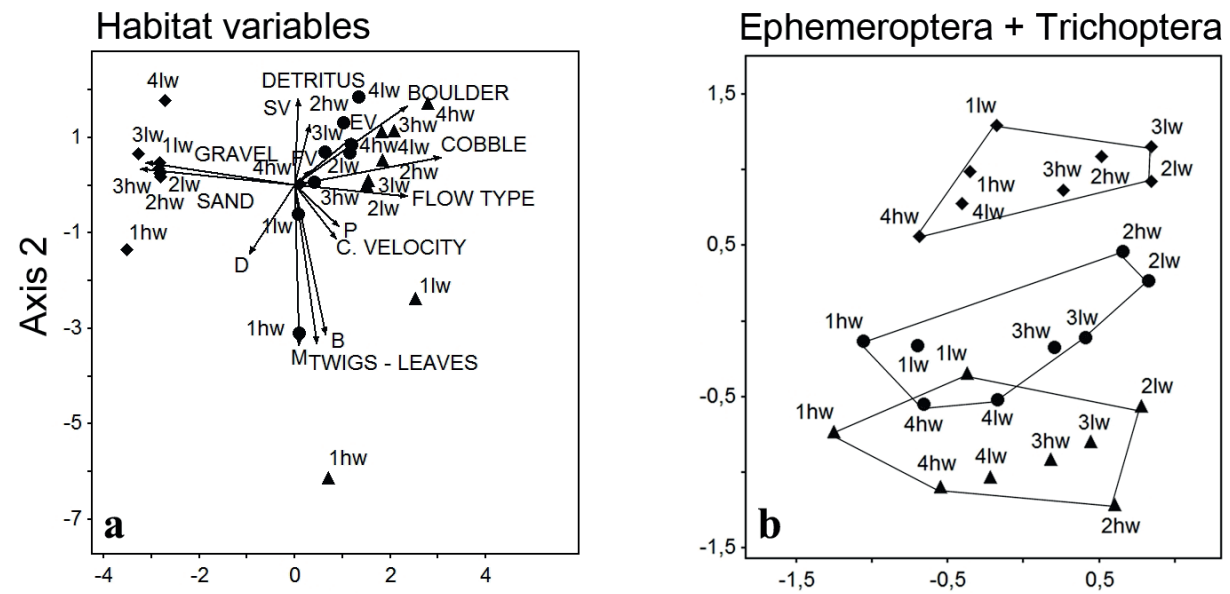

\section{Ephemeroptera}

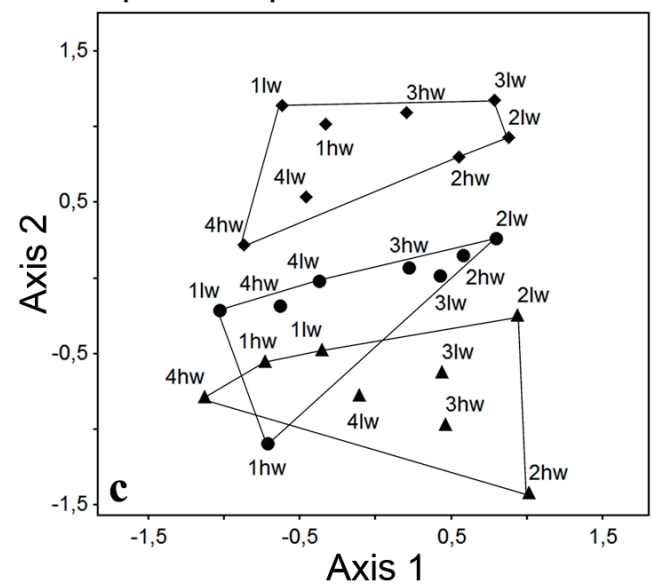

Trichoptera

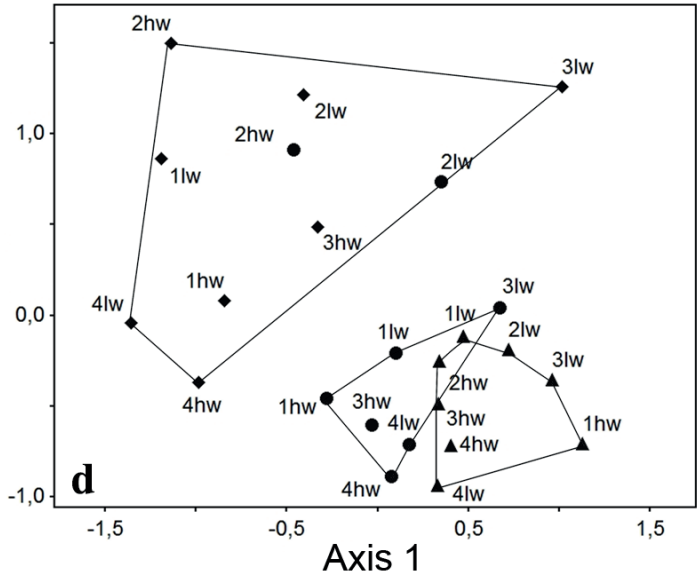

Figure 3 - PCA of habitat variables (plot a) and NMDS of Ephemeroptera+Trichoptera assemblages (plot b), Ephemeroptera (plot c) and Trichoptera (plot d) in 3 different stream habitats: riffles (triangles), coarse substrate runs (circles) and fine substrate runs (diamond) in 4 streams $(1,2,3,4)$ during high (hw) and low water periods (lw). Each dot corresponds to the average of 3 spatial replicates, 2 temporal replicates, and 2 reaches.

in environmental data. Axis 1 explained $27.47 \%$ of environmental variation and was negatively correlated with gravel and sand and positively related to cobble, boulder and flow type (Table I). Axis 2 explained $19.85 \%$ of environmental data and was negatively correlated with bedrock (Table I), twigs-leaves $(r=-0.85)$ and macroalgae $(r=$ $-0.86)$.

Twelve Ephemeroptera taxa belonging to 4 families and thirteen taxa of nine Trichoptera families were found (Table II). Although Plecoptera species are part of the EPT group, they were not found at study sites. Three out of the twelve genera collected of Ephemeroptera have a neotropical distribution and one family, Leptohyphidae, is exclusive of America. Within the 9 families of Trichoptera collected, three genera of different families have a neotropical distribution and two other genera are exclusively found on the American continent.

Seven taxa of the collected Ephemeroptera had a relative frequency $>50 \%$ (i.e., taxon was collected in at least 144 benthic samples from a total of 288). Americabaetis spp. was the most frequent (99.7\% relative frequency) and abundant taxon followed by Leptohyphes spp. and Tricorythodes spp. both with a relative frequency of $95.8 \%$. LMMs showed an influence of habitat type on the abundance of all 
TABLE II

List of Trichoptera and Ephemeroptera taxa and results of Lineal Mixed Models (LMM) applied on taxa abundance. LMM were applied only to taxa with relative frequency $>10 \%$. LMM compared abundance among three habitats (R: riffles, C: coarse substrate runs, $\mathrm{F}$ : fine substrate runs.), between two hydrological periods (H: high water period, L: low water period) and interaction terms. Only significant p values are shown. Degrees of freedom ${ }_{(\text {factor, error) }}$ : Habitat ${ }_{(2,192)}$, Period $_{(1,192)}$, Habitat $\times$ Period $_{(2,192)}$. DGC: Di RienzoGuzman-Casanoves post-hoc test.

\begin{tabular}{|c|c|c|c|c|}
\hline & Significant factor & $\mathbf{F}$ & $\mathbf{p}$ & DGC post-hoc test \\
\hline \multicolumn{5}{|l|}{ EPHEMEROPTERA } \\
\hline \multicolumn{5}{|l|}{ Baetidae } \\
\hline Americabaetis spp. & Habitat $\times$ Period & 7.58 & 0.0006 & $\mathrm{CL}=\mathrm{FH}=\mathrm{FL}>\mathrm{CH}=\mathrm{RH}=\mathrm{RL}$ \\
\hline Apobaetis spp. & \multicolumn{4}{|c|}{ LMM was not applied (relative frequency 7\%) } \\
\hline Baetodes spp. & Habitat & 3.16 & 0.0497 & $\mathrm{R}>\mathrm{C}=\mathrm{F}$ \\
\hline Camelobaetidius spp. & Habitat $\times$ Period & 5.21 & 0.0062 & $\mathrm{RL}>\mathrm{CH}>\mathrm{RH}=\mathrm{CL}>\mathrm{FH}>\mathrm{FL}$ \\
\hline Cloeodes spp. & \multicolumn{4}{|c|}{ LMM was not applied (relative frequency $1.5 \%$ ) } \\
\hline Nanomis spp. & Habitat $\times$ Period & 11.38 & $<0.0001$ & $\mathrm{CL}>\mathrm{RL}=\mathrm{FL}=\mathrm{CH}=\mathrm{FH}=\mathrm{RH}$ \\
\hline Paracloeodes spp. & Habitat & 42.20 & $<0.0001$ & $\mathrm{~F}>\mathrm{C}>\mathrm{R}$ \\
\hline \multirow{2}{*}{ Varipes spp. } & Habitat & 9.40 & 0.0002 & $\mathrm{~F}>\mathrm{C}>\mathrm{R}$ \\
\hline & Period & 19.24 & 0.0071 & $\mathrm{H}>\mathrm{L}$ \\
\hline \multicolumn{5}{|l|}{ Caenidae } \\
\hline Caenis spp. & Habitat & 11.77 & $<0.0001$ & $\mathrm{~F}>\mathrm{C}>\mathrm{R}$ \\
\hline \multicolumn{5}{|l|}{ Leptohyphidae } \\
\hline \multirow{2}{*}{ Leptohyphes spp. } & Habitat & 31.71 & $<0.0001$ & $\mathrm{R}>\mathrm{C}>\mathrm{F}$ \\
\hline & Period & 35.00 & 0.0006 & $\mathrm{~L}>\mathrm{H}$ \\
\hline Tricorythodes spp. & Habitat $\times$ Period & 6.93 & 0.0012 & $\mathrm{FL}=\mathrm{FH}=\mathrm{CL}>\mathrm{RL}=\mathrm{CH}=\mathrm{RH}$ \\
\hline \multicolumn{5}{|l|}{ Leptophlebiidae } \\
\hline Farrodes spp. & Habitat & 8.08 & 0.0004 & $\mathrm{R}=\mathrm{C}>\mathrm{F}$ \\
\hline \multicolumn{5}{|l|}{ TRICHOPTERA } \\
\hline \multicolumn{5}{|l|}{ Hydropsychidae } \\
\hline Smicridea spp. & Habitat & 11.27 & $<0.0001$ & $\mathrm{R}>\mathrm{C}=\mathrm{F}$ \\
\hline \multicolumn{5}{|l|}{ Philopotamidae } \\
\hline Chimarra spp. & Habitat & 21.79 & $<0.0001$ & $\mathrm{R}>\mathrm{C}>\mathrm{F}$ \\
\hline \multicolumn{5}{|l|}{ Polycentropodidae } \\
\hline Polycentropus spp. & Habitat & 4.37 & 0.0136 & $\mathrm{C}=\mathrm{R}>\mathrm{F}$ \\
\hline \multicolumn{5}{|l|}{ Hydrobiosidae } \\
\hline Cailloma spp. & \multicolumn{4}{|c|}{ LMM was not applied (relative frequency $0.5 \%$ ) } \\
\hline \multicolumn{5}{|l|}{ Glossosomatidae } \\
\hline Mexitrichia sp. & Habitat $\times$ Period & 3.23 & 0.0500 & $\mathrm{RL}=\mathrm{CL}=\mathrm{CH}>\mathrm{RH}=\mathrm{FH}=\mathrm{FL}$ \\
\hline Protoptila spp. & Habitat & 12.76 & $<0.0001$ & $\mathrm{R}>\mathrm{C}=\mathrm{F}$ \\
\hline \multicolumn{5}{|l|}{ Hydroptilidae } \\
\hline Hydroptila spp. & \multicolumn{4}{|c|}{ LMM was not applied (relative frequency 5\%) } \\
\hline Metrichia spp. & Habitat & 4.94 & 0.0224 & $\mathrm{R}>\mathrm{C}=\mathrm{F}$ \\
\hline Neotrichia spp. & \multicolumn{4}{|c|}{ LMM was not applied (relative frequency $1 \%$ ) } \\
\hline Oxyethira spp. & Habitat $\times$ Period & 3.72 & 0.0255 & $\mathrm{RH}>\mathrm{CH}=\mathrm{CL}=\mathrm{RL}=\mathrm{FH}=\mathrm{FL}$ \\
\hline \multicolumn{5}{|l|}{ Leptoceridae } \\
\hline Nectopsyche spp. & \multicolumn{4}{|c|}{ LMM was not applied (relative frequency $5 \%$ ) } \\
\hline \multicolumn{5}{|l|}{ Helicopsychidae } \\
\hline Helicopsyche spp. & \multicolumn{4}{|c|}{ LMM was not applied (relative frequency $4 \%$ ) } \\
\hline \multicolumn{5}{|l|}{ Odontoceridae } \\
\hline Marilia spp. & Habitat $\times$ Period & 3.05 & 0.0500 & $\mathrm{CL}=\mathrm{RL}=\mathrm{RH}>\mathrm{FH}=\mathrm{CH}=\mathrm{FL}$ \\
\hline
\end{tabular}


Ephemeroptera taxa but this effect interacted with the hydrological period in most of the taxa (Table II). The hydrological period did not show influence on the abundance of Baetodes spp., Farrodes spp. Paracloeodes spp. and Caenis spp. Baetodes spp. were more abundant in riffles and Farrodes spp. were also abundant in riffles and in coarse substrate runs whereas Paracloeodes spp. and Caenis spp. were more abundant in fine substrate runs (Table III). In spite of the ubiquity of Americabaetis spp., this mayfly was more abundant in fine substrate runs and in coarse substrate runs during the low water period (Table II). Varipes spp. and Tricorythodes spp. were also more abundant in fine substrate runs. Leptohyphes spp. presented its higher abundance in riffles (Table III) and Camelobaetidius spp. was also more abundant in riffles and coarse substrate runs during the high water period. The density of Nanomis spp. was higher in coarse substrate runs during the low water period although it was not a frequent taxon (10\% relative frequency). Apobaetis spp. and Cloeodes spp. were the least frequent mayflies ( $7 \%$ and $1.5 \%$ relative frequency, respectively). Cloeodes spp. was exclusively collected in coarse substrate runs and Apobaetis spp. was more abundant in fine substrate runs (Table III).

Contrary to the observed in the Ephemeroptera group, only one taxon of Trichoptera had a relative frequency $>50 \%$ (Marilia spp., 58.3\% relative frequency). Chimarra spp. was the most abundant taxon and had a relative frequency of $42.4 \%$. Smicridea spp. was also abundant and presented $38.5 \%$ of relative frequency. The other Trichoptera taxa were much less abundant and all of them had a relative frequency $<20 \%$ (i.e. taxon was collected in less than 58 benthic samples from a total of 288). LMMs showed an influence of habitat type on the abundance of all Trichoptera taxa but, contrary to what we found for Ephemeroptera, the hydrological period has an effect on few taxa (Table II). The hydrological period showed influence on the abundance of Mexitrichia spp., Oxyethira spp. and Marilia spp. All Trichoptera showed higher density in riffles and coarse substrate runs (Table III). Chimarra spp., Smicridea spp., Protoptila spp. and Metrichia spp. were much more abundant in riffles habitats (Table III) and Polycentropus spp. were abundant not only in riffles but also in coarse substrate runs. The density of Marilia spp. was also higher in riffles and in coarse substrate runs during the low water period. Least frequent Trichoptera showed preference for riffles habitats except Helicopsyche spp., which was found equally in all stream habitats (Table III).

Rarefaction analysis performed with the Ephemeroptera data set showed that coarse substrate runs in the high water period presented the highest richness (Fig. 4a, Table IV). The richness of Trichoptera was similar among habitats (Fig. 4b, Table IV); but when we included both Ephemeroptera and Trichoptera taxa in rarefaction analysis, two main groups of habitat types were clearly differentiated: on the one hand, riffles and coarse substrate runs during the high water period, which presented high richness values (Fig. 4c, Table IV); and on the other hand, fine substrate runs with the lowest richness values (Table IV). Coarse substrate runs during the low water period presented intermediate richness values (Table IV) showing, therefore, an influence of the hydrological period on richness in this habitat type.

NMDS applied on Ephemeroptera +Trichoptera data set clearly distinguished assemblages associated to the different stream habitats (Fig. 3b, stress $=0.157$, ANOSIM: $\mathrm{R}=0.5523, \mathrm{p}=0.0001$ ). NMDS performed with Ephemeroptera data set strongly differentiate assemblages associated with fine substrate runs, whereas assemblages from riffles and coarse substrate runs resulted rather overlapped (Fig. 3c, stress=0.117, ANOSIM: $\mathrm{R}=0.3916, \mathrm{p}=0.0001$ ). A similar pattern was observed for Trichoptera (Fig. $3 \mathrm{~d}$, stress $=0.175$, 
TABLE III

Mean total abundance (ind. $\mathrm{m}^{-2}$ ) of Ephemeroptera and Trichoptera ( \pm standard error) in different habitats of the study streams. The highest mean values of abundance are in bold.

\begin{tabular}{|c|c|c|c|}
\hline & RIFFLES & COARSE SUBSTRATE RUNS & FINE SUBSTRATE RUNS \\
\hline \multicolumn{4}{|l|}{ Ephemeroptera } \\
\hline Americabaetis spp. & $4998 \pm 1270$ & $6833 \pm 827$ & $7720 \pm 697$ \\
\hline Apobaetis spp. & $7 \pm 4$ & $4 \pm 2$ & $21 \pm 10$ \\
\hline Baetodes spp. & $\mathbf{5 4 9} \pm 116$ & $12 \pm 5$ & $11 \pm 6$ \\
\hline Camelobaetidius spp. & $2033 \pm 341$ & $853 \pm 137$ & $72 \pm 18$ \\
\hline Cloeodes spp. & $0 \pm 0$ & $\mathbf{3} \pm 2$ & $0 \pm 0$ \\
\hline Nanomis spp. & $3 \pm 1$ & $\mathbf{4 0} \pm 12$ & $3 \pm 2$ \\
\hline Paracloeodes spp. & $55 \pm 15$ & $254 \pm 70$ & $2317 \pm 635$ \\
\hline Varipes spp. & $307 \pm 67$ & $576 \pm 134$ & $\mathbf{1 3 0 9} \pm 249$ \\
\hline Caenis spp. & $327 \pm 146$ & $462 \pm 69$ & $790 \pm 133$ \\
\hline Leptohyphes spp. & $\mathbf{4 0 1 6} \pm 508$ & $3018 \pm 491$ & $892 \pm 121$ \\
\hline Tricorythodes spp. & $1698 \pm 231$ & $4980 \pm 596$ & $\mathbf{9 7 0 7} \pm 1862$ \\
\hline Farrodes spp. & $147 \pm 40$ & $119 \pm 21$ & $15 \pm 7$ \\
\hline \multicolumn{4}{|l|}{ Trichoptera } \\
\hline Chimarra spp. & $\mathbf{9 2 5} \pm 206$ & $205 \pm 134$ & $3 \pm 1$ \\
\hline Cailloma spp. & $\mathbf{1} \pm 1$ & $0 \pm 0$ & $0 \pm 0$ \\
\hline Smicridea spp. & $379 \pm 115$ & $29 \pm 9$ & $3 \pm 1$ \\
\hline Polycentropus spp. & $9 \pm 3$ & $\mathbf{1 1} \pm 4$ & $1 \pm 1$ \\
\hline Mexitrichia spp. & $32 \pm 9$ & $25 \pm 8$ & $1 \pm 1$ \\
\hline Protoptila spp. & $25 \pm 7$ & $8 \pm 3$ & $1 \pm 1$ \\
\hline Hydroptila spp. & $\mathbf{2 4} \pm 17$ & $1 \pm 1$ & $1 \pm 1$ \\
\hline Oxyethira spp. & $\mathbf{5 3} \pm 34$ & $8 \pm 2$ & $0 \pm 0$ \\
\hline Metrichia spp. & $\mathbf{5 1} \pm 27$ & $2 \pm 1$ & $1 \pm 1$ \\
\hline Neotrichia spp. & $2 \pm 1$ & $0 \pm 0$ & $0 \pm 0$ \\
\hline Nectopsyche spp. & $\mathbf{5} \pm 3$ & $3 \pm 2$ & $0 \pm 0$ \\
\hline Marilia spp. & $61 \pm 14$ & $104 \pm 30$ & $48 \pm 9$ \\
\hline Helicopsyche spp. & $1 \pm 1$ & $1 \pm 1$ & $2 \pm 1$ \\
\hline
\end{tabular}

ANOSIM: $\mathrm{R}=0.3909, \mathrm{p}=0.0001$ ) with a higher variability within fine substrate runs.

The RDA performed with Ephemeroptera data set showed that taxa responded to habitat variables, mainly substrate and flow type (Fig. 5a). Monte Carlo permutation test showed that all axes were significant $(\mathrm{F}: 2.411, \mathrm{p}=0.002)$ demonstrating then a good relationship between taxa distribution and habitat variables. Proportion of boulder, cobble, gravel, sand, flow type and detritus were the most important variables explaining taxa distribution. The two first ordination axes explained 54.9\% of the variance of species data and $41.7 \%$ of species-environment relation (Eigenvalues: Axis 1: 0.342; Axis 2: 0.207). Trichoptera taxa were also influenced by habitat variables, mainly flow and substrate, according to the RDA results (Fig. 5b). Monte Carlo permutation test showed that all axes were significant (F: 2.041, p = 0.014) and the most important variables explaining taxa distribution were similar to those found for Ephemeroptera taxa: proportion of bedrock, boulder, cobble, gravel and sand, flow type, macroalgae and leaves and twigs. The two first ordination axes explained 

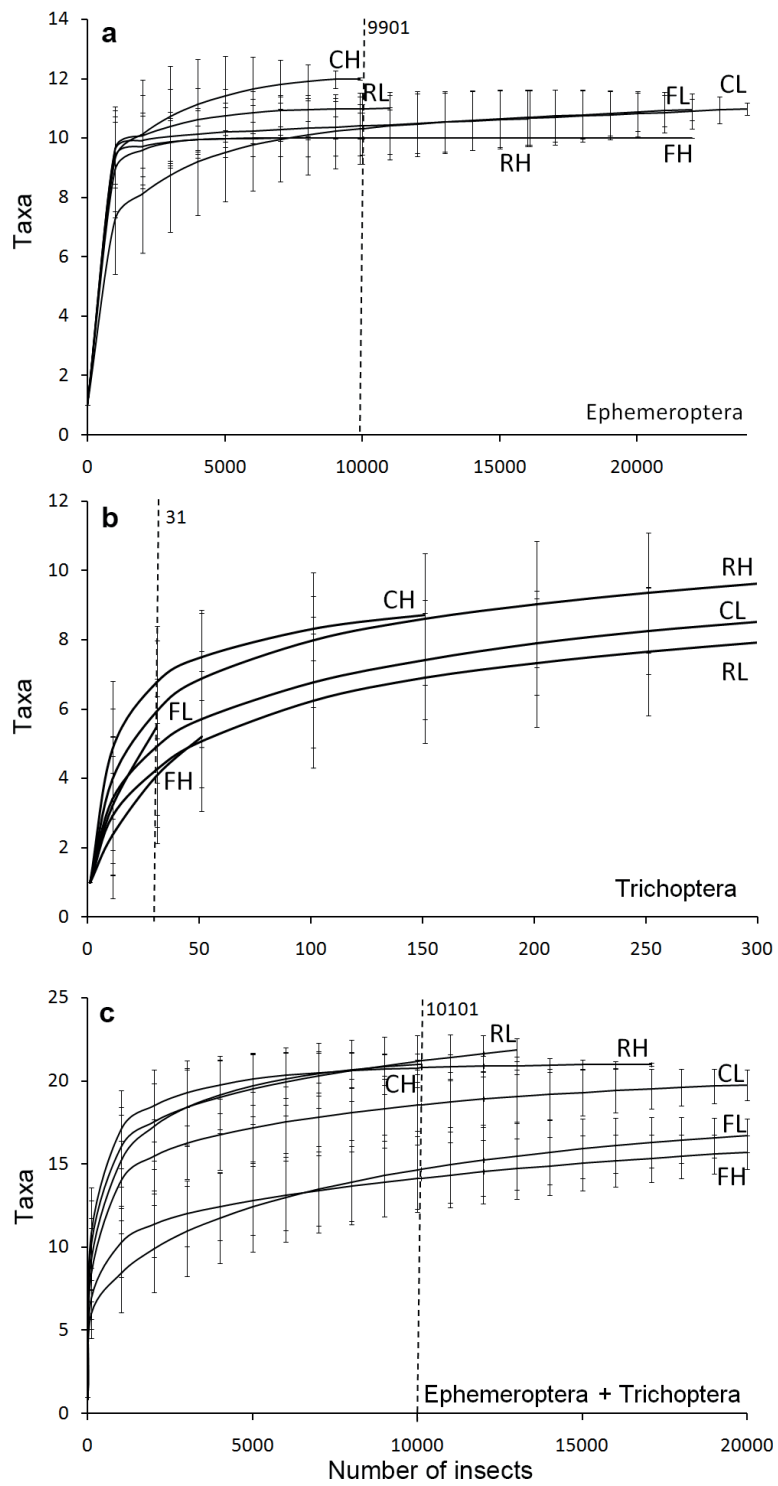

Figure 4 - Rarefaction curves based on the number of individuals of: a) Ephemeroptera assemblage, b) Trichoptera assemblage and c) Ephemeroptera +Trichoptera assemblage in different habitats ( $\mathrm{R}$ : riffles, $\mathrm{C}$ : coarse substrate runs, F: fine substrate runs) during two hydrological periods ( $\mathrm{H}$ : high water period, L: low water period). The minimum number of individuals is indicated with a dashed line. Confidence intervals are shown and they are specified in Table IV.

$55.8 \%$ of the variance of species data and $48.5 \%$ of species-environment relation (Eigenvalues: Axis 1: 0.385; Axis 2: 0.173).

The different stream habitats assessed in this study sustain a characteristic assemblage of Ephemeroptera and Trichoptera. Table V summarized main taxa associated with each habitat and the most important variables conditioning taxa distribution according to the results of LMMs and RDAs. Notice that riffles differed from coarse substrate runs in flow type (flow with waves in riffles and rippled flow in coarse substrate runs) and this latest habitat differed from fine substrate runs in substrate type.

\section{DISCUSSION}

In this study, we found differences in composition of the assemblages at the habitat level according to our expectations. Although we also expected temporal differences, our results showed that the hydrological period had more influence on Ephemeroptera taxa than on Trichoptera, similar to the findings of Baptista et al. (2001). We found that habitat variables conditioned taxa abundance and we were able to identify the habitat preference of each taxon, the most important variables affecting distribution patterns, and the stream habitat with the highest richness.

The different stream habitats assessed in this study sustain a characteristic assemblage of Ephemeroptera and Trichoptera. As we expected, riffles maintained the highest richness whereas the fine substrate runs presented the lowest one. Several studies reported similar results (Tickner et al. 2000, Baptista et al. 2001, Principe 2008, Brand et al. 2012), with high diversity in the most heterogeneous habitat (i.e., riffles) and a low diversity in the most homogeneous (i.e., fine substrate runs). The coarse substrate runs become important in allocating high diversity during the high water period, probably acting as an alternative habitat for refuge during floods. The heterogeneous environments are preferred by many species since they offer refugia and proper conditions for feeding (Wahl et al. 2013). On the other hand, in habitats of fine substrate, the instability of the substrate and the low organic matter availability lead to a low diversity 
TABLE IV

Mean expected number of species with $95 \%$ confidence intervals. Rarefaction 1000 permutations, minimum Ephemeroptera: CS Runs - high water = 9901; Trichoptera: FS Runs -low water = 31; Ephemeroptera + Trichoptera: CS Runs - high water $=10101$.

\begin{tabular}{cccc}
\hline & Ephemeroptera & Trichoptera & Ephemeroptera + Trichoptera \\
\hline Riffles - High water & $10.00(9.98-10.02)$ & $5.93(3.77-8.09)$ & $20.79(19.96-21.62)$ \\
Riffles - Low water & $11.00(10.85-11.14)$ & $4.25(2.16-6.33)$ & $21.20(19.65-22.75)$ \\
CS runs - high water & 12.00 & $6.77(4.94-8.60)$ & 20.98 \\
CS runs - low water & $10.41(9.42-11.39)$ & $4.91(2.91-6.91)$ & $18.63(16.70-20.42)$ \\
FS Runs - high water & $10.00(9.98-10.02)$ & $4.09(2.14-6.04)$ & $14.15(12.13-16.16)$ \\
FS Runs - low water & $10.32(9.12-11.51)$ & 5.48 & $14.67(12.32-17.02)$ \\
\hline
\end{tabular}

TABLE V

Ephemeroptera and Trichoptera taxa associated to each habitat and the most important variables conditioning taxa distribution according to the results of LMM and RDA. Flow types found in each habitat are shown between brackets.

\begin{tabular}{|c|c|c|}
\hline Habitat type & Taxa & Habitat variables \\
\hline \multirow{10}{*}{ Riffles } & Baetodes spp. & Beadrock \\
\hline & Camelobaetidius spp. & Boulder \\
\hline & Leptohyphes spp. & Cobble \\
\hline & Farrodes spp. & Flow type (broken and unbroken standing waves) \\
\hline & Chimarra spp. & Macroalgae \\
\hline & Smicridea spp. & Leaves and twigs \\
\hline & Mexitrichia spp. & Detritus \\
\hline & Protoptila spp. & \\
\hline & Oxyethira spp. & \\
\hline & Metrichia spp. & \\
\hline \multirow{6}{*}{ Coarse substrate runs } & Nanomis spp. & Boulder \\
\hline & Polycentropus spp. & Cobble \\
\hline & Marilia spp. & Flow type (rippled) \\
\hline & & Macroalgae \\
\hline & & Leaves and twigs \\
\hline & & Detritus \\
\hline \multirow{6}{*}{ Fine substrate runs } & Americabaetis spp. & Gravel \\
\hline & Paracloeodes spp. & Sand \\
\hline & Varipes spp. & Flow type (rippled and smooth surface flow) \\
\hline & Caenis spp. & Macroalgae \\
\hline & Tricorythodes spp. & Leaves and twigs \\
\hline & & Detritus \\
\hline
\end{tabular}

and richness (Gualdoni et al. 2009). Surprisingly, when considering only the Ephemeroptera taxa, fine substrate runs emerged as an important habitat for these taxa. Richness in riffles was higher given that most genera of Trichoptera were associated with this habitat. However, a half of the collected genera of Ephemeroptera were mainly associated with fine substrate runs and with high abundances (nearly dominant in the benthic community).

Our results showed that Camelobaetidius spp., Baetodes spp., Leptohyphes spp. and Farrodes spp. were mainly associated with riffles whereas 

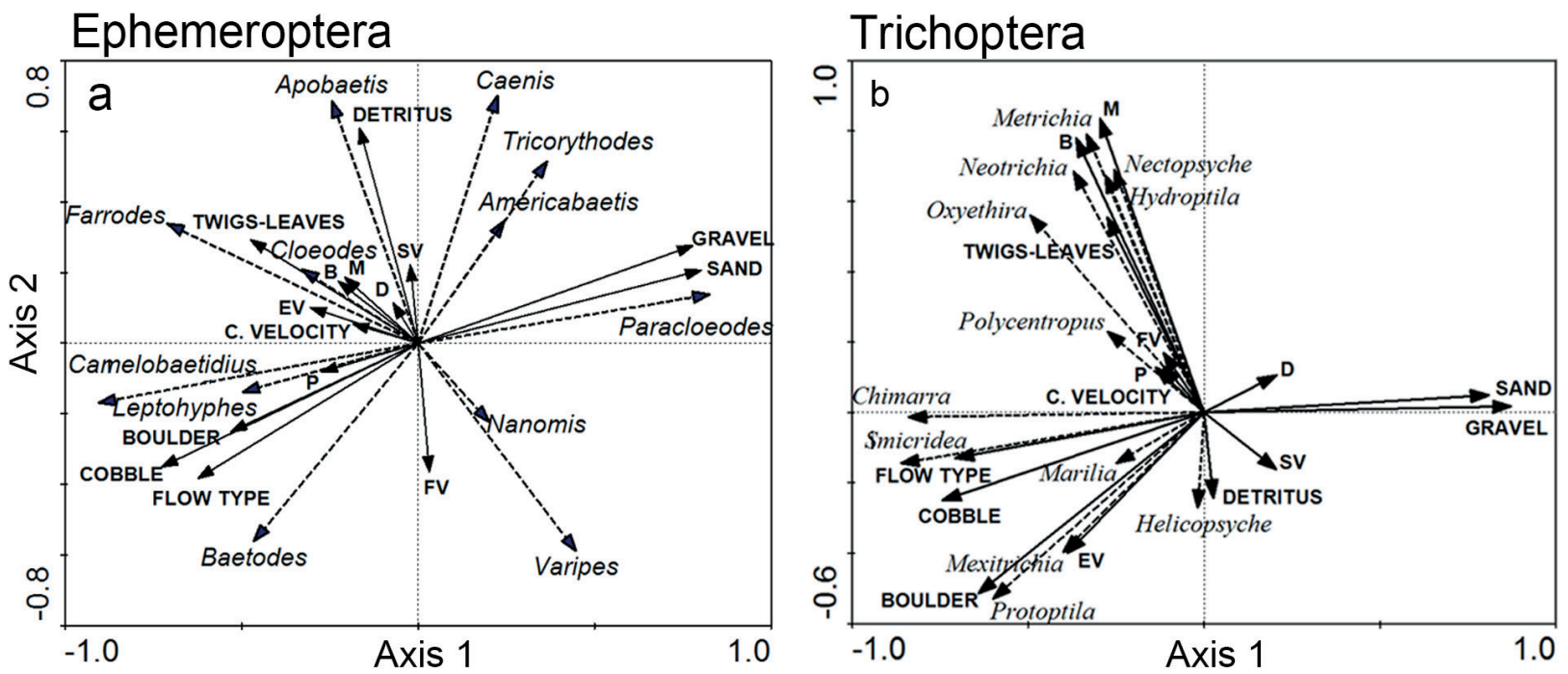

Figure 5 - RDA of Ephemeroptera (a) and Trichoptera (b) with environmental variables from different habitats of the study streams (Carcarañá River upper Basin, Córdoba, Argentina). Dashed arrows correspond to genera and solid arrows correspond to habitat variables.

Americabaetis spp., Paracloeodes spp., Varipes spp., Tricorythodes spp. and Caenis spp. had a preference for fine substrate runs. Some of these findings agree with other studies (Edmunds and Waltz 1996, Pérez and Segnini 2005, Domínguez et al. 2009) but, contrary to our findings, Domínguez et al. 2009 reported Americabaetis spp. mainly associated with macrophyte patches and in our study, we found a strong association of this genus to fine substrate runs in which macrophytes were practically absent. Nanomis spp. was the only Ephemeroptera associated to coarse substrate runs but it was not an abundant taxon (mean abundance in coarse substrate runs $=40$ ind. $\mathrm{m}^{-2}$ ). In the same drainage catchment, but at higher altitudes, this genus was abundant in riffles of first-order streams (Principe et al. 2015, mean abundance in riffles = 1100 ind. $\mathrm{m}^{-2}$ ) and, as only one species of this genus is present in Argentina (Salles and Nieto 2008, Chacón et al. 2013), this therefore suggests that this species is more characteristic of small streams at higher altitudes than to our studied middle streams.

None of the thirteen Trichoptera found in our study showed preference by the fine substrate runs. Most of the genera were mainly associated to riffles.
Chimarra spp., Smicridea spp. and Protoptila spp. have already been reported mainly associated with erosional habitats (Wiggins 1996) with rocky substrate (Angrisano and Sganga 2009). We found Oxyethira spp. also in riffles and the RDA showed a strong association with the presence of macroalgae, which agree with other studies (Wiggins 1996, Angrisano and Sganga 2009). Mexitrichia spp. and Protoptila spp., both belonging to the family Glossosomatidae, were mainly associated with riffles. Nevertheless, Protoptila spp. showed higher affinity by this habitat whereas Mexitrichia spp. also showed higher densities in coarse substrate runs, showing therefore, an eurytopic behavior in habitat selection. This result suggests that these two genera, with similar food and materialcase requirements (Angrisano and Sganga 2009, Principe et al. 2010), partition the habitat in order to optimize the use of resources.

We found that substrate and flow type were important predictors defining assemblages in our study streams. Macroalgae and organic matter (twigs, leaves, and detritus) also influenced distribution patterns. Similar results were reported by other studies (Schmera and Erõs 2004, Arimoro 
and Muller 2010, Brand et al. 2012) but no influence of substrate type on Trichoptera taxa have also been reported (Vásquez-Ramos et al. 2014). At a catchment scale, temperature, substrate, water quality and current velocity were reported as the most important factors determining longitudinal distribution of Ephemeroptera (Mishra and Nautiyal 2011, Jiang et al. 2013) and for Trichoptera, stream order, slope, temperature and conductivity were cited (Bispo et al. 2006, Hughes 2006). At a smaller scale (habitat level), current velocity and substrate type would be the most important variables (Schmera and Erõs 2004, Brand et al. 2012), which agree with our findings.

In our study, flow type was an important variable determining taxa distribution along the selected habitats as shown by the RDA ordination but surprisingly, current velocity was not. This finding agrees with those reported by Brand et al. (2012) and several studies have already stated that the assessment of flow characteristics is critical in analyses of habitat availability and organism distribution within streams (Thomson et al. 2001, Belletti et al. 2017). As surface flow characteristics are determined by the interaction of flow velocity, flow depth and substrate (Thomson et al. 2001), not only the effect of current velocity but also the effect of depth may have been integrated in the variable defined as flow type, and consequently, these two variables cannot be identified as important predictors of the assemblages in our study.

EPT assemblages differed among habitat types according to the expected. In addition, variables defining the habitats, mainly flow and substrate type, had a strong influence on taxa abundance, which showed seasonal variation in some cases. Our study provides valuable ecological information related to habitat preference of taxa with a key role in stream functioning and of great usefulness for the monitoring of lotic systems. We accurately document ecological preference at the habitat level based on a large data set taken from middle order streams of the Carcaraña River basin, a lotic system of great importance in the central region of Argentina. In addition, we identify the habitats to be preserved in order to guarantee the highest diversity and the conservation of some genera exclusive of a stream habitat. Although some bias may be associated to our results due to our approach did not identify species, it is highly probably that similar patterns will be obtain if species were evaluated since the most abundant genera (i.e Americabaetis, Leptohyphes and Tricorythodes) are known to have no more than two species each in our study area (Molineri, 2002, 2003, Bardavid and Nieto 2012). In addition, within the Trichoptera assemblage only Smicridea is expected to have several species (Sganga and Fontanarrosa 2006) and this genus was almost exclusively associated to riffles, which was the habitat with more richness. Then, patterns at the species level would show a similar pattern to those observed at genera level, being different only in the magnitude in which riffles (i.e. habitats with the highest richness) distinguish from fine substrate runs (i.e habitats with the lowest richness).

Based upon our findings, those human actions or disturbances that modify or eliminate riffles habitats in our studied middle reaches (e.g., large dams are being planned), will reduce Ephemeroptera and Trichoptera richness. The fine substrate runs must also be considered, which, contrary to the commonly reported, sustained the same richness of Ephemeroptera found in riffles and allocated exclusive taxa. Therefore, water managers should take extra-care with these habitats. In addition, since the ephemeropterans had different composition on each substrate, diversity measures should consider habitat heterogeneity and include different habitats in bioassessment. The presence of a range of refugia, each likely to be used by different sets of species, is largely responsible for the increment of resilience and resistance of the system (Sheldon et al. 2010, Hershkovitz and Gasith 2013) which may be of great importance for the recovery 
after disturbance. These results are applicable for outlining management and conservation strategies for middle reaches of mountain streams in central Argentina as well as other similar environments at a global scale.

\section{ACKNOWLEDGMENTS}

We thank to M. Gualdoni, A. Oberto, G. Raffaini for their help with field and laboratory tasks and M. Corigliano for inspiring the development of this research. We also thank anonymous reviewers for their comments and suggestions that improved the early version of the manuscript. This study has been supported by Secretaría de Ciencia y Técnica, Universidad Nacional de Río Cuarto, Argentina.

\section{AUTHOR CONTRIBUTIONS}

REP conceived the investigation and collected field data. REP, JAM and LCM processed samples, analyzed and interpreted data, and wrote the manuscript.

\section{REFERENCES}

ALLAN JD AND CASTILLO MM. 2007. Stream Ecology: Structure and Function of Running Waters. Second Edition, Netherlands: Springer, $436 \mathrm{p}$.

ANGRISANO EB AND SGANGA JV. 2009. Trichoptera. In: Domínguez E and Fernández HR (Eds), Macroinvertebrados Bentónicos Sudamericanos, Sistemática y Biología, Tucumán, Argentina: Fundación M. Lillo, p. 255-307.

ARIMORO FO AND MULLER WJ. 2010. Mayfly (Insecta: Ephemeroptera) community structure as an indicator of the ecological status of a stream in the Niger Delta area of Nigeria. Environ Monit Assess 166: 581-594.

BAPTISTA DF, BUSS DF, DORVILLÉ LFM AND NESSIMIAN JL. 2001. Diversity and habitat preference of aquatic insects along the longitudinal gradient of the Macaé river basin, Rio de Janeiro, Brazil. Rev Bras Biol 61: 249-258.

BARBER-JAMES HM, GATTOLLIAT J, SARTORI M AND HUBBARD MD. 2008. Global diversity of mayflies (Ephemeroptera, Insecta) in freshwater. Hydrobiologia 595: 339-350.
BARDAVID S AND NIETO C. 2012. Primer registro de cuatro especies del género Americabaetis (Ephemeroptera: Baetidae) para Argentina. Rev Soc Entomol Argent 71: 169-172.

BELLETTI B, RINALDI M, BUSSETTINI M, COMITI F, GURNELL AM, MAO L, NARDI L AND VEZZA P. 2017. Characterising physical habitats and fluvial hydromorphology: A new system for the survey and classification of river geomorphic units. Geomorphology 283: 143-157.

BISPO PC, OLIVEIRA LG, BINI LM AND SOUSA KG. 2006. Ephemeroptera, Plecoptera and Trichoptera assemblages from riffles in mountain streams of central Brazil: environmental factors influencing the distribution and abundance of immatures. Braz J Biol 66: 611-622.

BONADA N, PRAT N, RESH VH AND STATZNER B. 2006. Developments in aquatic insect biomonitoring: a comparative analysis of recent approaches. Annu Rev Entomol 51: 495-523.

BRAND C, MISERENDINO ML AND EPELE LB. 2012. Spatial and temporal pattern of caddisfly distribution at a mesohabitat scale in two Patagonian mountain streams subjected to pastoral use. Int Rev Hydrobiol 97: 83-99.

CABIDO D, CABIDO M, GARRE SM, GORGAS JA, MIATELLO R, RAMBALDI S, RAVELO A AND TASSILE JL. 2003. Regiones Naturales de la Provincia de Córdoba. Serie C. Publicaciones Técnicas. Córdoba, Argentina: Agencia Córdoba, Dirección de Ambiente, 103 p.

CHACÓN MM, PESCADOR ML AND SEGNINI S. 2013. New species of Nanomis Lugo-Ortiz and McCafferty, 1999 (Ephemeroptera: Baetidae) from Venezuela. Aquat Insects 35: 1-14.

CORTES RMV, HUGHES SJ, PEREIRA VR AND VARANDAS SDGP. 2013. Tools for bioindicator assessment in rivers: the importance of spatial scale, land use patterns and biotic integration. Ecol Indic 34: 460-477.

DI RIENZO JA, CASANOVES F, BALZARINI MG, GONZALEZ L, TABLADA M AND ROBLEDO CW. 2012. InfoStat versión 2012. Grupo InfoStat, FCA, Universidad Nacional de Córdoba, Argentina. <http:// www.infostat.com.ar>.

DOMÍNGUEZ E AND FERNÁNDEZ HR. 2009. Macroinvertebrados Bentónicos Sudamericanos, Sistemática y Biología. Tucumán, Argentina: Fundación M. Lillo, 654 p.

DOMÍNGUEZ E, MOLINERI C AND NIETO C. 2009. Ephemeroptera. In: Domínguez E and Fernández HR (Eds), Macroinvertebrados Bentónicos Sudamericanos, Sistemática y Biología, Tucumán, Argentina: Fundación M. Lillo, p 55-93. 
DOS SANTOS DA, RUEDA MARTÍN PA AND REYNAGA MC. 2015. Spatial patterns of caddisflies from Austral South America. Syst Biodivers 13: 419-433.

DOS SANTOS DA ET AL. 2018. Cold/Warm stenothermic freshwater macroinvertebrates along altitudinal and latitudinal gradients in Western South America: A modern approach to an old hypothesis with updated data. J Biogeogr 45: 1571-1581.

EDMUNDS GF AND WALTZ RD. 1996. Ephemeroptera. In: Merritt RW and Cummins KW (Eds), An introduction to the Aquatic Insects of North America, Iowa, USA: Kendall/Hunt Publishing Company, p. 126-163.

FLOURY M, USSEGLIO-POLATERA P, DELATTRE C AND SOUCHON Y. 2017. Assessing long-term effects of multiple, potentially confounded drivers in ecosystems from species traits. Glob Change Biol 23: 2297-2307.

FRISSELL CA, LISS WJ, WARREN CE AND HURLEY MD. 1986. A hierarchical framework for stream habitat classification: viewing streams in a watershed context. Environ Manage 10: 199-214.

GAZENDAM E, GHARABAGHI B, ACKERMAN JD AND WHITELEY H. 2016. Integrative neural networks models for stream assessment in restoration projects. J Hydrol 536: 339-350.

GEIST J. 2011. Integrative freshwater ecology and biodiversity conservation. Ecol Indic 11: 1507-1516.

GORDON ND, MCMAHON TA, FINLAYSON BL, GIPPEL CJ AND NATHAN RJ. 2004. Stream Hydrology: An Introduction for Ecologists. Second Edition, Chichester, England: Wiley and Sons, 429 p.

GREENBERG AE, CLESCERI LS AND EATON AD. 1992. Standard Methods for the Examination of Water and Wastewater. Washington: American Public Health Association.

GUALDONI CM, BOCCOLINI MF, OBERTO AM, PRINCIPE RE, RAFFAINI GB AND CORIGLIANO MC. 2009. Potencial habitats vs. Functional habitats in a lowland braided river (Córdoba, Argentina). Ann Limnol Int J Lim 45: 69-78.

HAMMER Ø, HARPER DAT AND RYAN PD. 2001. Paleontological Statistics Software: Package for Education and Data Analysis. Palaeontol Electron 4.

HAUER FR AND RESH VH. 2017. Macroinvertebrates. In: Hauer FR and Lamberti GA (Eds), Methods in Stream Ecology, Volume 1, $3^{\text {rd }}$ ed., London, UK: Academic Press, p. 297-319.

HAWKINS CP ET AL. 1993. A hierarchical approach to classifying stream habitat features. Fisheries 18: 3-12.

HERSHKOVITZ AND GASITH A. 2013. Resistance, resilience, and community dynamics in mediterraneanclimate streams. Hydrobiologia 719: 59-75.
HUGHES SJ. 2006. Temporal and spatial distribution patterns of larval Trichoptera in Madeiran streams. Hydrobiologia 553: $27-41$

JIANG X, XIE Z AND CHEN Y. 2013. Longitudinal patterns of macroinvertebrate communities in relation to environmental factors in a Tibetan-Plateau river system. Quatern Int 304: 107-114.

LENAT DR AND RESH VH. 2001. Taxonomy and stream ecology - the benefits of genus and species-level identification. J N Am Benthol Soc 20: 287-298.

LIGEIRO R, HUGHES RM, KAUFMANN PR, MACEDO DR, FIRMIANO KR, FERREIRA WR, OLIVEIRA D, MELO AS AND CALLISTO M. 2013. Defining quantitative stream disturbance gradients and the additive role of habitat variation to explain macroinvertebrate taxa richness. Ecol Indic 25: 45-57.

MAC NALLY R, WALLIS E AND LAKE PS. 2011. Geometry of biodiversity patterning: assemblages of benthic macroinvertebrates at tributary confluences. Aquat Ecol 45: $43-54$

MC CUNE B, GRACE JB AND URBAN DL. 2002. Analysis of Ecological Communities (Vol. 28). Gleneden Beach, OR: MjM software design.

MELO AS. 2005. Effects of taxonomic and numeric resolution on the ability to detect ecological patterns at a local scale using stream macroinvertebrates. Arch Hydrobiol 164: 309-323.

MISHRA AS AND NAUTIYAL P. 2011. Factors governing longitudinal variation in benthic macroinvertebrate fauna of a small Vindhyan river in Central Highlands ecoregion (central India). Trop Ecol 52: 103-112.

MOLINERI C. 2002. Cladistic analysis of the South American species of Tricorythodes (Ephemeroptera: Leptohyphidae) with the description of new species and stages. Aquat Insect 24: 273-308.

MOLINERI C. 2003. Revision of the South American species of Leptohyphes Eaton (Ephemeroptera: Leptohyphidae) with a key to the nymphs. Stud Neotrop Fauna E 38: 47-70.

MYKRÄ H, HEINO J AND MUOTKA T. 2007. Scale-related patterns in the spatial and environmental components of stream macroinvertebrate assemblage variation. Glob Ecol Biogeogr 16: 149-159.

NESTLER JM, BAIGÚN C AND MADDOCK I. 2016. Achieving the aquatic ecosystem perspective: integrating interdisciplinary approaches to describe instream ecohydraulic processes. In: Gilvear DJ, Greenwood MT, Thoms MC and Wood PJ (Eds), River Science: Research and Management for the $21^{\text {st }}$ Century, Chichester, UK: John Wiley \& Sons, p. 84-102.

NIETO C. 2010. Cladistic analysis of the family Baetidae (Insecta: Ephemeroptera) in South America. Syst Entomol 35: 512-525. 
PÉREZ B AND SEGNINI S. 2005. Variación espacial de la composición y diversidad de géneros de Ephemeroptera (Insecta) en un río tropical altiandino. Entomotropica 20: 49-57.

PRINCIPE RE. 2008. Taxonomic and size structures of aquatic macroinvertebrate assemblages in different habitats of tropical streams, Costa Rica. Zool Stud 47: 525-534.

PRINCIPE RE, GUALDONI CM, OBERTO AM, RAFFAINI GB AND CORIGLIANO MC. 2010. Spatial-temporal patterns of functional feeding groups in mountain streams of Córdoba, Argentina. Ecología Austral 20: 257-268.

PRINCIPE RE, MÁRQUEZ JA, CIBILS MARTINA L, JOBBÁGY EG AND ALBARIÑO RJ. 2015. Pine afforestation changes more strongly community structure than ecosystem functioning in grassland mountain streams. Ecol Indicat 57: 366-375.

R CORE TEAM. 2013. R: a language and environment for statistical computing. Vienna, Austria: R Foundation for Statistical Computing. <http://www.R-project.org/>.

RESH V, NORRIS R AND BARBOUR M. 1995. Design and implementation of rapid assessment approaches for water resource monitoring using benthic macroinvertebrates. Aust J Ecol 20: 108-121.

SALLES FF, MASSARIOL FC, ANGELI KB, LIMA MM, GATTOLLIAT JL AND SARTORI M. 2015. Revealing the diversity of Cloeodes Traver, 1938 (Ephemeroptera: Baetidae) in the Neotropics: description of eleven new species from Brazilian mountain ranges. Zootaxa 4020: $1-50$.

SALLES FF AND NIETO C. 2008. Los estados adultos de Nanomis y Spiritiops (Ephemeroptera: Baetidae). Rev Soc Entomol Argent 67: 35-39.

SCHMERA D AND ERÕS T. 2004. Effect of riverbed morphology, stream order and season on the structural and functional attributes of caddisfly assemblages. Ann Limnol Int J Lim 40: 193-200.

SGANGA JV AND FONTANARROSA MS. 2006. Contribution to the knowledge of the preimaginal stages of the genus Smicridea McLachlan in South America (Trichoptera: Hydropsychidae: Smicrideinae). Zootaxa 1258: $1-15$.

SHELDON F, BUNN SE, HUGHES JM, ARTHINGTON AH, BALCOMBE SR AND FELLOWS CS. 2010. Ecological roles and threats to aquatic refugia in arid landscapes: dryland river waterholes. Mar Freshwater Res 61: 885895.

STATZNER B, HOPPENHAUS K, ARENS MF AND RICHOUX P. 1997. Reproductive traits, habitat use and templet theory: a synthesis of world-wide data on aquatic insects. Freshwater Biol 38: 100-135.

TER BRAAK CJF AND SMILAUER P. 1998. CANOCO reference manual and user's guide to Canoco for Windows: software for canonical community ordination (version 4). Centre for Biometry, $352 \mathrm{p}$.

TER BRAAK CJF AND SMILAUER P. 1999. CANOCO for Windows (Version 4.02) A FORTRAN Program for Canonical Community Ordination. Centre for Biometry, Wageningen, The Netherlands.

THOMSON JR, TAYLOR MP, FRYIRS KAAND BRIERLEY GJ. 2001. A geomorphological framework for river characterization and habitat assessment. Aquat Conserv 11: 373-389.

TICKNER D, ARMITAGE PD, BICKERTON MA AND HALL KA. 2000. Assessing stream quality using information on mesohabitat distribution and character. Aquat Conserv 10: 170-196.

TOWNSEND CR AND HILDREW AG. 1994. Species traits in relation to a habitat templet for river system. Freshwater Biol 31: 265-276.

UNDERWOOD AJ. 1994. Spatial and temporal problems with monitoring. In: Calow P and Petts G (Eds), The Handbook of River, Oxford: Blackwell, p.182-204.

VALENTE-NETO F, RODRIGUES ME AND DE OLIVEIRA RF. 2018. Selecting indicators based on biodiversity surrogacy and environmental response in a riverine network: Bringing operationality to biomonitoring. Ecol Indic 94: 198-206.

VÁSQUEZ-RAMOS JM, GUEVARA-CARDONA G AND REINOSO-FLÓREZ G. 2014. Environmental factors associated with habitat preferences by caddisfly larvae in tropical dry forest watersheds (Tolima, Colombia). Rev Biol Trop 62: 21-40.

WIGGINS GB. 1996. Trichoptera families. In: Merritt RW and Cummins KW (Eds), An Introduction to the Aquatic Insects of North America, Iowa, USA: Kendall/Hunt Publishing Company, p 309-349.

WAHL CM, NEILS A AND HOOPER D. 2013. Impacts of land use at the catchment scale constrain the habitat benefits of stream riparian buffers. Freshwater Biol 58: 2310-2324.

WARFE DM, BARMUTA LA AND WOTHERSPOON S. 2008. Quantifying habitat structure: surface convolution and living space for species in complex environments. Oikos 117: 1764-1773.

\section{SUPPLEMENTARY MATERIAL}

Table SI - Location of study sites in streams of Carcarañá River basin (1: Río de los Sauces, 2: El Talita, 3: Las Cañitas, 4: Piedras Blancas) and physico-chemical characterization of water during high and low water periods. Mean values are shown with standard deviations. Dissolved oxygen was measured only once at each site and hydrological period. TDS: Total dissolved solids. Coordinates delimit stream segment that included sampled reaches. 